\title{
Sepsis update: management of severe sepsis and septic shock in the emergency department after the withdrawal of Xigris
}

\begin{abstract}
Robert S. Green, BSc, MD, FRCPC*; Dennis Djo
Xigris, a systemic anticoagulant used for the manage-
ment of patients with severe sepsis and septic shock, has recently been removed from the market. Also known as drotrecogin alfa (activated) or activated protein $\mathrm{C}$, this medication is no longer available for use. Recommendations and guidelines (including the Canadian Association of Emergency Physicians [CAEP] sepsis guidelines ${ }^{1}$ ) require revision to reflect this important development. ${ }^{1}$

The story of Xigris serves as a cautionary tale, which has both advanced and distracted the care of patients with severe sepsis/septic shock. Few emergency physicians may be aware of the history of this medication, the controversy surrounding it, and evidence leading to its use and subsequent termination as a treatment option.
\end{abstract}

\section{THE XIGRIS STORY}

The pathophysiology of sepsis is complex, and the medical literature is ripe with promising medications thought to be of potential benefit based on physiologic principles but that have not translated into clinical utility. ${ }^{2}$ Multiple cytokines and other molecules thought to be important in the pathophysiology of severe sepsis and septic shock have been identified, but attempts to influence these biochemical pathways have been disappointing. ${ }^{3}$

Early data on Xigris indicated a significant antiinflammatory effect and a possible improvement in outcome in patients with sepsis. Subsequent clinical investigations culminated in a phase III clinical trial (PROWESS), which demonstrated a 6.1\% absolute mortality benefit in patients with severe septic shock who received Xigris. ${ }^{4}$ However, controversy surrounded the evidence for Xigris. The PROWESS study was terminated early for efficacy after both a protocol alteration and a modification in the production of the drug compound occurred midtrial. ${ }^{5,6}$ Despite these factors, Xigris was approved by the Food and Drug Administration (FDA) under the following conditions: 1) that it be used only in patients with severe sepsis (an APACHE II score > 25) and 2) follow-up data on the efficacy and safety were to be supported by Eli Lilly, the manufacturer. Xigris was widely adopted for use in severe sepsis and septic shock.

The cost of the drug was set in the range of $\$ 8,000$ to $\$ 10,000 /$ treatment, which challenged hospital budgets. Eli Lilly instituted an extensive marketing campaign to promote the use of Xigris on a global scale. Given the burden of severe sepsis and septic shock worldwide, the potential for a substantial return on the development investment was enormous. One particular promotion included funding of a group of experts to develop recommendations for the management of severe sepsis and septic shock, which included the use of Xigris and directly supported the initial "Surviving Sepsis" campaign and guidelines. ${ }^{7,8}$ Xigris became entrenched as a standard in severe sepsis and septic shock despite minimal supporting evidence, and physicians were ethically inclined to use Xigris on a routine basis.

From the *Department of Emergency Medicine and Division of Critical Care Medicine, Department of Anesthesia, Queen Elizabeth II Health Science Centre, Capital Health, and Department of Emergency Medicine, Dalhousie University, Halifax, NS; +University of Alberta, Edmonton, AB; and $\neq$ Division of Critical Care, Department of Emergency Medicine, Queen's University, and Kingston Resuscitation Institute, Kingston, ON.

Correspondence to: Dr. Robert S. Green, Department of Emergency Medicine, Division of Critical Care Medicine, Department of Anesthesia, Room 377 Bethune Building, 1276 South Park Street, Halifax, NS B3H 2Y9; Dr.Robert.Green@dal.ca.

This article has been peer reviewed. 
Concerns regarding Xigris arose when data from additional investigations by Eli Lilly on Xigris use in children and patients with less severe sepsis indicated both a lack of benefit and the possibility of harm. ${ }^{9,10}$ Skepticism mounted, and calls for a confirmatory clinical trial in patients with severe sepsis and septic shock increased. Ultimately, the PROWESS-SHOCK trial was initiated to address the concerns. ${ }^{11}$

The PROWESS-SHOCK trial did not confirm the findings of the original PROWESS trial. Fortunately, there seemed to be no indication that Xigris was associated with an increased incidence of severe adverse events (Xigris $1.2 \%$ vs. placebo $1.0 \%$ ). However, 28 day mortality in the 1,680 patients was not statistically different between patients receiving Xigris (26.4\%) compared to placebo (24.2\%). Consequently, the drug was withdrawn from the market by Eli Lilly.

\section{REFLECTIONS ON XIGRIS AND SEVERE SEPSIS}

There has been variable fallout in the medical community after the withdrawal of Xigris, ranging from anger and fuel for cynicism to the thought that it is part of medication development. It is estimated that the culminated sales had reached $\$ 1.5$ billion globally since FDA approval in 2001. ${ }^{12}$ At best, we have been treating the sickest septic shock patients with an expensive medication that has no benefit, and at worst we have wasted money and research resources on a potentially harmful drug. There are many lessons to be learned here for all of us.

However, one view should not be lost in the chaos: sepsis care has improved dramatically in the 10 years since Xigris has been released, not in small part to the promotion of Xigris..$^{13,14}$ Although perhaps not the ultimate intention, the marketing for Xigris has served to educate many on the importance of patient identification and the institution of care in an expedient manner. It is probable that if Xigris had not been released, there would not have been substantial funding for, and dissemination of sepsisrelated information, including cohesive and relevant clinical guidelines for the care of septic patients.

What does this mean for emergency medicine? First, the emergency care of septic patients should not change because this medication was used as therapy once patients arrived in the intensive care unit. We should continue to strive to identify septic patients early, administer broad-spectrum antimicrobials expediently, resuscitate aggressively, and attempt source control, as outlined in the CAEP sepsis guidelines. 'Second, emergency physicians can learn valuable lessons from the Xigris story. There is always good and bad when considering the agenda of pharmaceutical companies. We need to continue to hold a healthy skepticism when considering all medical medications and interventions. In this case, we should not have had to wait 10 years and spent billions of dollars for an answer.

Competing interests: None declared.

Keywords: guidlines, serve sepsis, Xigvis

\section{REFERENCES}

1. Green RS, Djogovic D, Gray S, et al. CAEP Critical Care Interest Group. Canadian Association of Emergency Physicians sepsis guidelines: the optimal management of severe sepsis in Canadian emergency departments. CFEM 2008;10:443-59.

2. Russell JA. Management of sepsis. N Engl f Med 2006;355:1699713, doi:10.1056/NEJMra043632.

3. Zanotti S, Kumar A, Kumar A. Cytokine modulation in sepsis and septic shock. Expert Opin Investig Drugs 2002;11:1061-75, doi:10.1517/13543784.11.8.1061.

4. Bernard GR, Vincent JL, Laterre PF, et al. Recombinant Human Protein C Worldwide Evaluation in Severe Sepsis (PROWESS) study group. Efficacy and safety of recombinant human activated protein C for severe sepsis. N Engl 7 Med 2001;344:699-709, doi:10.1056/NEJM200103083441001.

5. Warren HS, Suffredini AF, Eichacker PQ, et al. Risks and benefits of activated protein $\mathrm{C}$ treatment for severe sepsis. $N$ Engl 7 Med 2002;347:1027-30, doi:10.1056/NEJMsb020574.

6. Siegel JP. Assessing the use of activated protein C in the treatment of severe sepsis. N Engl f Med 2002;347:1030-4, doi:10.1056/ NEJMsb021512.

7. Dellinger RP, Carlet JM, Masur H, et al. Surviving sepsis campaign guidelines for management of severe sepsis and septic shock. Crit Care Med 2004;32:858-73, doi:10.1097/01.CCM.0000117317.18092.E4.

8. Eichacker PQ, Natanson C, Danner RL. Surviving sepsispractice guidelines, marketing campaigns, and Eli Lilly. $N$ Engl 7 Med 2006;355:1640-2, doi:10.1056/NEJMp068197.

9. Abraham E, Laterre PF, Garg R, et al. Drotrecogin alfa (activated) for adults with severe sepsis and a low risk of death. $N$ Engl 7 Med 2005;353:1332-41, doi:10.1056/NEJMoa050935.

10. Nadel S, Goldstein B, Williams MD, et al. Drotrecogin alfa (activated) in children with severe sepsis: a multicentre phase III randomised controlled trial. Lancet 2007;369:836-43, doi:10.1016/ $\underline{\text { S0140-6736(07)60411-5. }}$.

11. Finfer S, Ranieri VM, Thompson BT, et al. Design, conduct, analysis and reporting of a multinational placebo-controlled trial of activated protein $\mathrm{C}$ for persistent septic shock. Intensive Care Med 2008;34:1935-47, doi:10.1007/s00134-008-1266-6.

12. Krauskopf L, Pierson R. UPDATE 4-Lilly pulls sepsis drug Xigris, no benefit found. Reuters.com US Edition. October 25,2011. Available at: http://www.reuters.com/article/2011/10/25/elililly-idUSN1E79O08 320111025 (accessed Dec 8, 2011).

13. Ferrer R, Artigas A, Levy MM, et al. Improvement in process of care and outcome after a multicenter severe sepsis educational program in Spain. FAMA 2008;299:2294-303, doi:10.1001/jama.299.19.2294.

14. Puskarich MA, Marchick MR, Kline JA, et al. One year mortality of patients treated with an emergency department based early goal directed therapy protocol for severe sepsis and septic shock: a before and after study. Crit Care 2009;13:R167. [Epub 2009 Oct 21], doi:10.1186/cc8138. 